\title{
Pengembangan Media Interaktif Berbasis Aplikasi Unity Dalam Berpikir Kritis
}

\author{
Zalfa Ulayya M1', Irna Khaleda ${ }^{2}$, Iis Nurasiah ${ }^{3}$ \\ 1Universitas Muhammadiyah Sukabumi, Sukabumi, Indonesia \\ 2 Universitas Muhammadiyah Sukabumi, Sukabumi, Indonesia \\ 3 Universitas Muhammadiyah Sukabumi, Sukabumi, Indonesia \\ *Corresponding author: zalfaulayya299@gmail.com
}

\begin{abstract}
After conducting a preliminary study, it turned out that in one of the public elementary schools in the Overtime sub-district, Sukabumi City, there were obstacles in carrying out the learning process, especially in social studies subjects. At these schools, the educators have not used learning media so that learning is monotonous and boring. The purpose of this study was to determine the feasibility of unity-based interactive media in critical thinking in social studies subjects for class IV and to determine the response of students to interactive media. In this study, the type of research is Research and Development. The researcher used an instrument in the form of a validation questionnaire for the feasibility of the media and conducted a test of the ability of students. Product data analysis was carried out by media experts and practitioners to determine student responses after using the learning media that the author had developed. In this study, the authors analyze the quality of learning media, analyze student responses and analyze students' ability tests. The results of this study after using the learning media that researchers have developed there is an increase in learning in critical thinking.
\end{abstract}

keywords: critical thinking; interactive media

\section{ABSTRAK}

Setelah melakukan studi pendahuluan ternyata di salah satu sekolah dasar negeri di kecamatan lembur situ kota sukabumi memiliki kendala dalam melakukan proses pembelajaran terutama pada mata pelajaran IPS. Pada sekolah tersebut tenaga pendidik belum menggunakan media pembelajaran sehingga pembelajaran monoton dan membosankan. Tujuan dalam penelitian ini untuk mengetahui kelayakan media interaktif berbasis unity dalam berpikir kritis pada mata pelajaran IPS kelas IV dan mengetahui respon peserta didik terhadap media interaktif. Pada penelitian ini mengguanakan jenis penelitian Research and Development. Peneliti menggunakan intrumen berupa angket validasi untuk kelayakan media dan melakukan tes kemampuan peserta didik. Analisis data produk dilakukan oleh ahli media dan praktisi untuk mengetahui respon peserta didik sesudah menggunakan media pembelajaran yang sudah penulis kembangkan. Dalam penelitian ini penulis menganalisis kualitas media pembelajaran, menganalisis respon peserta didik dan menganalisis tes kemampuan peserta didik. Hasil dari penelitian ini setelah menggunakan media pembelajaran yang sudah peneliti kembangkan ada peningkatan belajar dalam berpikir kritis.

kata kunci: berpikir kritis; media interaktif 


\section{Pendahuluan}

Menurut Y Siska, (2018) Pada umumnya IPS di artikan sebagai program pendidikan yang mengatur atau setirnya manusia dan masyarakat terhadap lingkungan, pembelajaran ilmu pengetahuan sosial ini di sesuaikan dengan umur siswa. Dan dapat disimpulkan bahwa pendidikan ilmu pengetahuan sosial merupakan :1) mata pelajaran yang di berikan pada sekolah dasar sampai sekolah menengah pertama, 2) mempelajari tingkah laku manusia, masyarakat terhadap lingkungan, 3) bahannya di ambil dari disiplin ilmu sosial.

Menurut Sapriya (dalam Siska, 2016:8) “tujuan pendidikan Ilmu Pengetahuan Sosial ini adalah mempersiapkan peserta didik untuk menguasai pengetahuan, keterampilan, nilai dan sikap, yang dapat di gunakan untuk memecahkan masalah dan mengambil keputusan dan berpastisipasi dalam masyarakat agar menjadi masyarakat yang lebih baik".

Setiap peserta didik memiliki kebutuhan yang berbeda Dalam proses kegiatan belajar mengajar pendidik dan peserta didik adalah komponen yang penting karena merekalah yang berinteraksi didalam kelas. Dalam kegiatan belajar mengajar yang terpenting adalah proses, karena proses inilah yang akan menjadi acuan tercapai atau tidaknya suatu tujuan pembelajaran. Ketercapaian suatu proses pembelajaran terlihat dari perubahan tingkah laku, perubahan tingkah laku ini meliputi baik secara kognitif, psikomotor dan afektif. Akan tetapi pada kenyataanya pendidik lebih sering berorientasi pada hasil dibandingkan berorientasi dengan proses, sehingga mengakibatkan kualitas seorang pendidik itu terabaikan. Dalam proses belajar mengajar ada beberapa faktor yang mempengaruhi tercapainya tujuan pembelajaran salah satunya yaitu media atau alat peraga. Untuk mencapai suatu tujuan pembelajaran media mempunyai peran yang sangat penting, media pembelajaran merupakan sarana yang dapat membantu proses pembelajaran karena berkaitan dengan indera penglihatan dan pendengaran. Dalam hal ini penulis akan mengembangkan media pembelajaran berbasis aplikasi Unity, dengan adanya media pembelajaran waktu lebih efektif dan efisien dalam suasana yang kondusif sehingga membuat pemahaman peserta didik lebih cepat.

Analisis kebutuhan yang penulis temukan dari hasil observasi dan disertai dengan hasil wawacara dengan wali kelas bahwa tenaga pendidik belum menggunakan media pembelajaran sehingga media pembelajaran ini dapat membantu guru untuk membawa suasana luar kelas menjadi ada di kelas, dengan demikian ide yang abstrak menjadi konkret dan mudah dimengerti oleh peserta didik. Sedangkan permasalahan yang ada di lapangan adalah pendidik tidak menguasai teknologi untuk mewujudkan sebuah media pembelajaran yang berbasis teknologi seperti komputer. Sebagian besar pendidik terkendala oleh teknis, program dan desain, sehingga media pembelajaran komputer hanya perpindahan dari media kertas ke media digital dengan tampilan yang sama, hal ini mengakibatkan media pembelajaran kurang optimal. Menurut Nita, (2018) “media pembelajaran adalah media yang dapat menyampaikan pesan pembelajaran atau mengandung muatan untuk membelajarkan seseorang" manfaat media pembelajaran adalah:1)Memperjelas pesan dari yang abstrak menjadi konkret.2) Dapat mengatasi sifat pasif pendidik.3) Mengatasi keterbatasan ruang, waktu, dan daya indra.4) Media ini dapat menyama ratakan kebutuhan siswa. 
Bahwa aplikasi Unity ini ternyata media pembelajaran yang jarang digunakan di banyak sekolah, bahwa salah satu sekolah yang belum menggunakan media aplikasi Unity adalah SDN Sindangsari Berdasarkan hasil observasi awal dengan melalui wawancara kepada wali kelas IV yaitu kepada wali kelas di sekolah SDN Sindangsari pada tanggal 02 Desember 2020 ditemukan permasalahan, yang penulis temukan dalam proses pembelajaran IPS antara lain adalah tenaga pendidik yang kurang kreatif sehingga anak merasa bosan, jenuh, tenaga pendidik kurang inovatif dan belum menggunakan media pembelajaran sehingga mengakibatkan anak pasif dan kurang bersemangat untuk mengikuti pembelajaran. Karena permasalahan tersebut berdampak pada masing - masing hasil belajar siswa tidak mencapai ketuntasan belajar. Di dalam mata pelajaran IPS itu salah satunya ada materi tentang karakteristik geografis Indonesi dan persebaran sumber daya alam, karakteristik geografis Indonesi dan persebaran sumber daya alam menjelaskan tentang persebaran sumber daya alam sesuai dengan daerah tempat tinggal, budaya Indonesia serta lapangan pekerjaan atau ekonomi yang sesuai dengan daerah tempat tinggal, selain tentang keberagaman budaya pada materi ini didalamnya ada materi tentang kerjasama dengan ASEAN, kita harus menghafal banyak tanggal dan tahun yang mungkin anak mudah tertukar dan susah untuk diingat karena ada sebagian anak yang mudah menghafal angka dan ada juga anak yang lebih mudah menghafal teks, materi tentang karakteristik geografis Indoenesia dan persebaran sumber daya alam ini kita harus mendengarkan guru bercerita atau hanya sekedar melihat film pendek saja, dengan menggunakan metode ceramah sehingga terjadi interaksi hanya satu arah, anak akan merasa bosan dan ngantuk karena konsentrasi anak bisa bertahan hanya 15 menit, lebih dari itu anak akan kehilangan konsentrasi dan tidak akan memperhatikan karena inilah mata pelajaran IPS terlihat akan membosankan.

Pada mata pelajaran ilmu pengetahuan sosial (IPS) ini lebih berpusat pada guru atau yang kita sebut Teacher Based Learning disini gurulah yang berperan penting yang seakan - akan guru adalah narasumber satu - satunya sumber informasi yang didapatkan oleh anak sehingga menyebabkan guru yang semakin cerdas dan anak hanya mendapatkan pengalaman mendengarkan saja. Dan dapat menyebabkan anak tidak berani bertanya dan takut untuk mencoba sesuatu hal. Posisi tenaga pendidik yang masih menerapkan transfer of knowladge apa yang disampaikan guru kepada anak selalu terpaku pada buku sehingga pendidik hanya memindahkan atau transfer ilmu dari buku menjadi lisan, dengan begitulah anak akan bosan untuk mendengarkan ceramah guru dan yang akhirnya membuat penyerapan ilmu anak tidak maksimal, ketika anak bosan mendengarkan penjelasan guru anak akan lebih senang berbicara dengan teman sebangkunya di buktikan dengan studi pendahuluan yang dilakukan oleh Ramadhani, (2018:44).

Dengan adanya kebutuhan di lapangan maka yang penulis tertarik untuk memberikan sebuah alternatif bagi guru dalam proses pembelajaran. Dengan cara menerapkan media pembelajaran berbasis aplikasi Unity yang dapat membantu guru untuk memecahkan masalahnya. Media interaktif berupa aplikasi ini akan mengubah kondisi pasif anak menjadi aktif, karena di dalam aplikasi ini tampilan nya menarik. Karena sekarang Indonesia masih terkena dampak covid 19 sehingga anak belajar dari rumah atau pembelajaran jarak jauh (PJJ). Sesuai dengan pendapat Syahroni et al.,( 2020) bahwa penggunaan media pembelajaran 
berbasis teknologi sangat penting bagi tenaga pendidik terutama pada pembelajaran jarak di masa pandemic covid 19. Bagi tenaga pendidik yang faham dengan pembuatan media pembelajaran berbasis teknologi ini akan sangan membantu proses pembelajaran dengan adanya aplikasi ini memudahkan pendidik dan siswa untuk belajar.

Ghirardini (dalam Adhe, 2018) mengatakan bahwa 'pendekatan daring dapat menggabungkan berbagai jens komponen daring, termasuk daring content, interaktif e-lesson, simulasi elektronik dan job aids. Interaktif e-lesson yakni pendekatan yang paling umum untuk self paced daring pelatihan berbasis web yang terdiri dari satu set interactive e-lessons. Sebuah elessons adalah urutan linear yang dapat mencakup teks, grafik, animasi, audio, video dan interaktivitas dalam bentuk pertanyaan dan umpan balik. E-lesson juga dapat mencakup rekomendasi membaca dan link ke sumber daya online, serta informasi tambahan tentang topik tertentu.' Penulis menggunakan aplikasi unity ini karena banyak fitur yang ditawarkan, UI yang ditawarkan cukup user-friendly, sehingga cocok untuk pemula, Dokumentasi atau tutorial yang banyak dan gratis untuk dipelajari resmi dari Unity. Silakan Anda dapat mengunjungi situs dokumentasi resminya, dan Ringan, yakni bisa dijalankan di PC yang tidak terlalu High-Spec. Aplikasi ini akan dikembangkan menjadi media aplikasi interaktif dimana didalamnya ada penggabungan anatara huruf dan gambar animasi yang menarik.

\section{Metode Penelitian}

Jenis penelitian yang digunakan dalam penelitian ini adalah Research anda Development. Menurut (Sugiyono, 2015:407) "penelitian yang digunakan untuk menghasilkan produk tertenutu, dan menguji keefektifan produk tersebut". Penelitian RnD ini digunakan untuk menjalankan penelitian dalam mencapai tujuan penelitian. Produk yang dihasilkan dari penelitian ini adalah media interaktif berbasis aplikasi Unity. Desain penelitian yang digunakan oleh penulis adalah desain penelitian Borg and Gall yang diadaptasi oleh (Sugiyono, 2015:409). Pada penelitian ini penenliti hanya menggunakan tujuh Langkah penelitian saja. Instrument yang digunakan dalam penelitian ini yaitu angket validasi para ahli, praktisi, serta respon siswa. Sedangkan untuk kemampuan peserta didik peneliti menggunakan tes. Test ini digunakan untuk mengukur kemampuan berpikir kritis peserta didik yang diperoleh siswa kelas IV setelah diterapkan media interaktif berbasis aplikasi Unity. Test disusun berdasarkan indikator yang hendak dicapai pada setiap proses kegiatan. Test kemampuan berpikir kritis dilaksanakan sebanyak dua kali, yaitu pretest dan posttest. Prosedur dalam penelitian ini adalah Langkah-langkah penelitian yang dilakukan oleh peneliti yaitu sebagai berikut : pada tahapan pertama yaitu potensi dan mencari permasalahan yang ada di sekolah yang akan dibahas oleh peneliti. Variabel yang dirumuskan ada dua jenis, yang pertama variable terikat dan kedua variable bebas, tahapan kedua menentukkan tempat dan subjek penelitian,dan pengumpulan data tempat penelitian yang ditentukan adalah SDN Sindangsari kota Sukabumi dengan peserta didik sebanyak 10 orang. Tahapan ketiga penulis menentukan kompetensi dasar yang sesuai dengan kemampuan peserta didik yang akan diukur dan mendesain produknya. Tahapan keempat penulis melakukan validasi desain pada ahli media, ahli materi dan guru. Tahapan kelima penulis melakukan perbaikan dari masukan-masukan yang diberikan oleh ahli media, ahli materi dan guru. Selanjutnya pada tahap ke enam ini penulis menguji coba produk media interaktif berbasis aplikasi Unity apakah bisa meningkatkan kemampuan 
berpikir kritis pada mata pelajaran IPS siswa kelas IV . Pada tahap akhir ketika semua langkah sudah dilakukan penulis melakukan revisi produk yang sudah diuji cobakan pada peserta didik. Pada tahapan terakhir yaitu setelah data diolah maka akan dibuat kesimpulan dengan melihat perolehan data yang ada dan sudah diolah, data yang telah ditentukan selanjutnya melakukan penyusunan laporan akhir penelitian.

\section{Hasil dan Pembahasan}

Produk dari penelitian ini yang dikembangkan ialah media pembelajaran interaktif . Menurut Anshori (dalam Masykhur \& Risnani, 2020) proses pembelajaran yang efektif dan efisien dapat terlaksana apabila pesan dan informasi pembelajaran tersampaikan dengan baik kepada siswa. Komponen komponen dalam pembelajaran yang dapat mendukung terciptanya komunikasi atau penyampaian informasi dengan baik, salah satunya adalah media pembelajaran untuk memahami kelayakan produk, para ahli dan praktisi melakukan validasi. Pada hal ini penulis memberikan Draft pertama kepada ahli dan praktisi kemudian ahli media mengajukan beberapa saran perbaikan. Ahli msteri dan praktisi tidak mengajukan perbaikan. Hasil evaluasi para ahli dan praktisi menunjukkan bahwa produk tersebut layak digunakan. Untuk mengetahui klasifikasi dan kategori produk maka harus melakukan analisis skor yang didapat dari skor validasi.

Kategori produk didasarkan pada hasil perhitungan menggunakan persamaan satu dan tabel lima skala. Hasil skor validitas dihitung berdasarkan 3 komponen yang memenuhi standar media pembelajaran. Analisis angket digunakan pada kelayakan isi dan tujuan dari praktisi, hasilnya adalah 33.5 yang termasuk kategori A dan kualifikasi Sangat Baik. Adapun hasil skor dari ahli materi yaitu 33 dan termasuk kategori A dan klasifikasinya A. jumlah skor ahli materi lebih kecil dari jumlah skor praktisi. Pada komponen intruksional, untuk hasil skor dari praktisi mendaptkan skor 24 dengan kategori B dan kualifikasi Baik, sedangkan hasil skor dari ahli media 25 dengan kategori A dan kualifikasi Sangat Baik. Selanjutnya pada komponen kualitas teknis dari ahli media mendapatkan skor 24 dengan kategori B, dan hasil skor dari ahli media mendapatkan 29.5 dengan kategori A.

Sedangkan hasil kemampuan berpikir kritis siswa dapat dianalisis dari hasil pretest dan posttest dilakukan pada tahap uji coba. Soal pretest terdapat 10 pilihan ganda dan 5 soal uraian soal tersebut berdasarkan indikator. Penggunaan media pembelajaran interaktif ini digunakan pada saat sesudah pretest dan sebelum postets. Materi yang digunakan dalam pembelejaran ini karakteristik geografis Indonesia dan persebaran sumber daya alam pada kelas IV sekolah dasar. Hasil pretest pada saat setelah menggunakan media pembelajaran memiliki peningkatan dari sebelum menggunakan media pembelajaran. Karena hal tersebut selaras dengan pendapat Yektyasti \& Ikhsan (Adriani \& Sabekti, 2018) bahwa media yang digunakan pada saat proses pembelajaran dapat menjadi alat bantu untuk mengatasi keterbatasan pendidik dalam menyampaikan materi serta keterbatasan waktu dalam mengajar.

Setelah mengolah data dari hasil pretest dan postetst dan hasilnya ada peningkatan. Pada uji coba memporeleh hasil perhitungan melalui gain score yaitu 0.65 pada bagian soal pilihan ganda dan skor 0.60 dari bagian soal uraian yang dikategorikan sedang. Sebagai 
seorang pendidik harus bisa menciptakan pembelajaran yang mampu melatih kemampuan berpikir kritis peserta didik untuk menemukan informasi belajar secara mandiri dan aktif menciptakan struktur kognitif pada peserta didik Patonah, (dalam Nuryanti et al., 2018)

Berdasarkan hal tersebut dapat disimpulkan bahwa berpikir kritis dapat meningkat dengan kategori sedang, meskipun mata pelajaran IPS sering dikenal dengan mata pelajaran yang membosankan Hal ini sejalan dengan pendapat (Kristin, 2018) mengatakan bahwa Ketika model pembelajaran pendidik menarik maka siswa ikut aktif dalam kegiatan proses pembelajaran sehingga siswa tidak merasa jenuh atau bosan ketika mengikuti pembelajaran dikelas.

Peningkatan pemahaman berpikir kritis tersebut terjadi karena peserta didik melalukan proses pembelajaran menggunakan media pembelajaran interaktif sehingga peserta didik dapat belajar secara aktif dan efektif. Dengan menggunakan media pembelajaran interaktif ini peseta didik lebih mudah dalam memahami materi pembelajaran. Pernyataan ini diperkuat dengan hasil nilai pretest yang rendah setelah peserta didik mendapatkan materi yang ada di dalam media pembelajaran hasil nilai postetst meningkat. Pendapat ini selaras dengan pendapat (Zulhelmi et al., 2017) bahwa media pembelajaran interaktif dapat membangkitkan keinginan belajar siswa, dan interaksi secara langsung antara siswa dan lingkungannya. Hal ini dapat menimbulkan minat siswa untuk belajar sendiri-sendiri sesuai dengan kemampuan yang dimiliki untuk meningkatkan prestasi belajar.

Setelah melakukan tes untuk mengetahui hasil berpikir kritis peserta didik, berikutnya melakukan pembagian angket untuk mengetahui respon siswa terhadap media pembelajaran yang dikembangkan oleh penulis. Berdasarkan kalimat diatas selaras dengan pendapat Nini, (2019) bahwa respon siswa terhadap media pembelajaran dapat berupa respon positif yang dijadikan sebagai tolak ukur, bahwa siswa merasa lebih nyaman dengan media pembelajaran yang digunakan dalam proses pembelajaran.

Setelah melakukan pembagian angket, maka hasil angket yang sudah dianalsisis persentase peserta didik yang diperoleh pada komponen isi dan tujuan 100\%, komponen intruksional $96.33 \%$ dan komponen teknis 93.33\% ketiga persentase ini menunjukkan kategori sangat kuat. Sedangkah jumlah kesuluruhan persenatse $97 \%$ dan berada di kategori sangat kuat. Hasil angket diatas diolah untuk mengetahui kategori dan persentase respon peserta didik menggunakan rumus skala likert Hasil skor diatas selaras dengan pendapat dari Maharani \& Widhiasih (Kartini \& Putra, 2020) yang mengatakan bahwa 'pembelajaran yang menarik membuat siswa lebih senang dan lebih mudah menyerap ilmu yang terlihat dari respon siswa selama proses pembelajaran. Respon siswa merupakan reaksi sosial yang dilakukan siswa dalam menanggapi pengaruh atau rangsangan dari situasi yang dilakukan orang lain.

\section{Kesimpulan}

Kelayakan media pembelajaran interaktif berbasis aplikasi Unity pada materi karakteristik geografis Indonesia dan persebaran sumber daya alam dihasilkan dari penialain ahli media, ahli materi dan praktisi, dengan hasil akhir untuk komponen isi dan tujuan 33.25 
termasuk kategori A dan klasifikasi sangat baik, komponen intruksional 24 dengan kategori B klasifiasi baik, dan komponen teknis mendapat skor 29.5 kategori A dan klasifikasi sangat baik. Pembelajaran menggunakan media interaktif berbasis aplikasi Unity dapat meningkatkan kemampuan berpikir kritis peserta didik. Kegiatan pembelajaran tersebut dilakukan satu kali uji coba dengan menggunakan instrument tes. Peningakatan tersebut dapat dibuktikan dengan hasil analisi data n gain 0.65 termask kategori sedang. Sedangkan respon siswa pada media pembelajaran interaktif berbasis aplikasi Unity ini berdasrkan hasil persentase dari setiap komponen yang sudah di rata- ratakan dan dari skor respon angket peserta didik, setiap komponen memiki persentase seperti komponen isi dan tujuan 100\%, komponen intruksional 96.33\% dan komponen teknis 93.33\%, jika dihitung keselruhan maka persenatse respon peserta didik $97 \%$ kategori sangat kuat.

\section{Daftar Pustaka}

Adhe, K. R. (2018). Pengembangan media pembelajaran daring matakuliah kajian PAUD di jurusan PG PAUD Fakultas Ilmu Pendidikan Universitas Negeri Surabaya. JECCE (Journal of Early Childhood Care and .... http://journal2.uad.ac.id/index.php/jecce/article/view/3

Adriani, N., \& Sabekti, A. W. (2018). TINGKAT KELAYAKAN MEDIA PEMBELAJARAN KIMIA BERBASIS ANDROID. Jurnal Zarah. http://ojs.umrah.ac.id/index.php/zarah/article/view/705

Kartini, K. S., \& Putra, I. (2020). PENGARUH PENGGUNAAN MEDIA PEMBELAJARAN INTERAKTIF BERBASIS ANDROID TERHADAP HASIL BELAJAR SISWA. JURNAL REDOKS (Jurnal Pendidikan

http://jurnal.stkipbima.ac.id/index.php/RE/article/view/417

Kristin, F. (2018). No Title. Meta-Analisis Pengaruh Model Pembelajaran Role Playing Terhadap Hasil Belajar IPS.

Masykhur, M. A., \& Risnani, L. Y. (2020). PENGEMBANGAN DAN UJI KELAYAKAN GAME EDUKASI DIGITALSEBAGAI MEDIA PEMBELAJARAN BIOLOGI SISWA SMA KELAS $X$ PADA MATERI ANIMALIA. BIOEDUKASI (Jurnal Pendidikan .... http://fkip.ummetro.ac.id/journal/index.php/biologi/article/view/3276

Nini, N. V. (2019). RESPON SISWA TERHADAP MEDIA PEMBELAJARAN INTERAKTIF BERBASIS FLASH PADA MATERI SEL KELAS XI DI SMAN 1 SANDAI KABUPATEN KETAPANG.

http://repository.unmuhpnk.ac.id/id/eprint/812

repository.unmuhpnk.ac.id.

Nita, I. D. K. dan S. (2018). Media Pembelajaran Berbasis Multimedia Interaktif untuk Meningkatkan Pemahaman Konsep Mahasiswa. Jurnal of Computer and Information Technology, 1.

Nuryanti, L., Zubaidah, S., \& Diantoro, M. (2018). Analisis kemampuan berpikir kritis siswa SMP. Jurnal Pendidikan: Teori http://journal.um.ac.id/index.php/jptpp/article/view/10490

Ramadhani, M. K. K. dan. (2018). permasalahan pembealajaran IPS dan Strategi jitu pemecahanannya. Ittihad, II. 
Siska, Y. (2018). Pembelajaran IPS di SD/MI. books.google.com. https:/ / books.google.com/books?hl=en\&lr=\&id=WN9MDwAAQBAJ\&oi=fnd\&pg=PR $1 \& d q=$ pembelajaran+ips\&ots $=$ OtunYDRMNT\&sig=5Md215rbDwPXwbdw_gZuu92Ntz0

Siska, Yulia. (2016). Konsep Dasar IPS (A. Wicaksono (ed.)). Garudhawaca.

Sugiyono. (2015). Metode Penelitian Pendidikan (Pendekatan Kuantitatif, Kualitatif dan RED). ALFABETA,CV.

Syahroni, M., Dianastiti, F. E., \& ... (2020). Pelatihan Media Pembelajaran Berbasis Teknologi Informasi untuk Meningkatkan Keterampilan Guru dalam Pembelajaran Jarak Jauh. International Journal of https://ejournal.undiksha.ac.id/index.php/IJCSL/article/view/28847

Zulhelmi, Z., Adlim, A., \& Mahidin, M. (2017). Pengaruh media pembelajaran interaktif terhadap peningkatkan keterampilan berpikir kritis siswa. Jurnal Pendidikan Sains .... http://www.jurnal.unsyiah.ac.id/JPSI/article/view/8414 